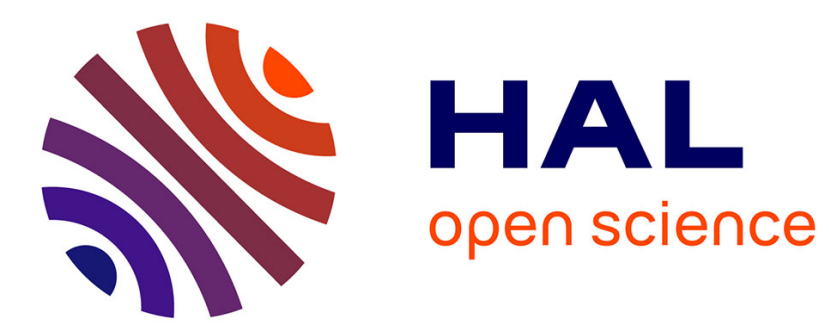

\title{
The dynamics of coordination in innovation networks
}

Elodie Gardet, Caroline Danièle Mothe

\section{To cite this version:}

Elodie Gardet, Caroline Danièle Mothe. The dynamics of coordination in innovation networks. European Management Review, 2011, 8 (4), pp.213-229. 10.1111/j.1740-4762.2011.01020.x . hal00919245v2

\section{HAL Id: hal-00919245 \\ https://hal.science/hal-00919245v2}

Submitted on 28 Jan 2014

HAL is a multi-disciplinary open access archive for the deposit and dissemination of scientific research documents, whether they are published or not. The documents may come from teaching and research institutions in France or abroad, or from public or private research centers.
L'archive ouverte pluridisciplinaire HAL, est destinée au dépôt et à la diffusion de documents scientifiques de niveau recherche, publiés ou non, émanant des établissements d'enseignement et de recherche français ou étrangers, des laboratoires publics ou privés. 


\title{
The dynamics of coordination in innovation networks
}

\author{
Elodie Gardet, Caroline Mothe
}

\begin{abstract}
Despite abundant literature dedicated to networks and coordination, few empirical studies address the internal operations of inter-organizational networks. This research therefore aims to characterise coordination mechanisms of various forms and analyse their evolution through an empirical analysis of six innovation networks. Three main dimensions determine the type of coordination adopted by a hub firm: its dependency, prior business relations, and type of conflict. The study also reveals a negative effect of a singular reliance on trust. Indirect guarantees need to combine with direct guarantees to facilitate hub firm dependence. Moreover, the coordination modes and the use of hard conflict resolution mechanisms vary with the type of conflict (i.e., project or behavioural). These findings have key implications for research and practice.
\end{abstract}

Keywords: coordination mechanisms; dependence; hub firm; innovation network. 


\section{Introduction}

Empirical studies of the internal operations of innovation networks are scarce (Ahuja, 2000;

Dhanaraj and Parkhe, 2006), most research focusing on the creation, structure or collapse of innovation networks. Yet, beyond these factors, networks comprise various elements, such as their ability to facilitate information exchange and expertise transfer while also encouraging opportunistic behaviours (Goerzen, 2007). For this study, we investigate coordination mechanisms in innovation networks, because firms must interact with others and manage these relationships to develop innovation projects. Innovation is key to competitive success (Dhanaraj and Parkhe, 2006), but innovation projects entail great transactional uncertainty and exchanges of tacit knowledge, requiring strategic efforts to maintain the network and extract value from it (Ahuja, 2000; Powell et al., 1996).

Hub firms expressly function to orchestrate innovation networks. Prior research on innovation network orchestration (e.g. Batterink et al., 2010; Dhanaraj and Parkhe 2006) typically has assumed that a commercial firm is the focal knowledge acquirer (e.g. Doz et al., 2000) but has not clarified the unique role of the 'network orchestrator' that exerts influence without any hierarchical authority (Dhanaraj and Parkhe, 2006). As Winch and Courtney (2007) warn, the question of how innovation hub firms operate and the conditions in which they are most effective remains unanswered (Batterink et al., 2010). Literature on coordination mechanisms highlights factors such as dependence (Gao et al., 2005; Grandori and Soda, 1995; Jiang et al., 2008), prior business relations (Jiang et al., 2008; Reuer and Arino, 2007) or the type of conflict (Das and Teng, 2002), though only individually (Das and Teng, 1998) and without analysing their detailed implementations. To remedy this situation, we investigate coordination mechanisms within innovation networks and their development throughout the process, thus answering our research question: How do dependence, prior business relations and the type of conflict affect coordination mechanisms, their forms and their development? 
In the next section, we offer a brief review of research into coordination mechanisms in innovation networks and discuss dependency according to resource dependency theory (Pfeffer and Salancik, 1978). We also address two dimensions that might influence coordination mechanisms: prior relations and type of conflict. By examining six innovation networks, we compare the coordination forms used by the hub firms over the course of their innovation projects and derive an answer to our research question. Finally, we conclude with some current limitations and avenues for further research.

\section{Theory}

Innovation networks-which consist of sets of vertical and horizontal relations established among various organizations that are orchestrated by a hub firm so it can take advantage of invention(s) — offer a fertile ground for understanding the evolving ways firms implement coordination mechanisms. A hub firm is one 'that possesses prominence and power gained through individual attributes and a central position in the network structure, and that uses its prominence and power to perform a leadership role in pulling together the dispersed resources and capabilities of network members' (Dhanaraj and Parkhe, 2006: 659). Having filed a patent application, the hub firm calls on network partners to transform its invention into an innovation, though in this process, it must regulate the transactions (Powell et al., 1996). The hub firm is central to innovation networks and has authority over other members, derived from its property rights; unlike $R \& D$ consortia, filed patents belong only to the hub firm. Moreover, by establishing the network, the hub firm has the most links with all other members (Drewello et $a l ., 2002)$ : It holds a central position and is in charge of most coordination mechanisms.

\section{Coordination mechanisms and innovation networks}

Coordination mechanisms are arrangements among economic entities that govern how they cooperate to develop an innovation project (Grandori and Soda, 1995). This definition centres on strategic interactions rather than operational ones (e.g. task distribution, communication). 
Similarly, prior research has proposed that coordination in inter-organizational relations can be achieved through strategic mechanisms such as reputation, trust, collective sanctions, working groups, procedures, costs and revenue-sharing rules (Das and Teng, 1998; Gilsing and Nooteboom, 2006; Grandori and Soda, 1995). In various typologies of coordination mechanisms, authors distinguish formal versus informal mechanisms, exchange regulation versus incentive or sanction schemes, or transactional versus relational modes. We avoid these simple classifications, which seem insufficient to analyse the different forms of each mechanism ${ }^{1}$. Yet the vast number of coordination mechanisms means we cannot be exhaustive. Instead, we focus on five representative, well-studied mechanisms: type of exchange and degree of formalisation, trust, shared benefits, guarantees and conflict resolution ${ }^{2}$ (see Appendix 1).

Type of exchange and degree of formalisation. Formal exchange mechanisms include standardised procedures, technical reports, analytical accounting, budgeting and planning, as well as confidentiality agreements and contracts (Das and Teng, 1998; Gulati, 1995a; Martinez and Jarillo, 1989). Informal exchanges, which are implicit and verbal, instead include the creation of joint teams (Grandori and Soda, 1995), seminars, meetings or staff transfers (Martinez and Jarillo, 1989), as well as decision-making methods. Informal modes are less costly (Gulati, 1995a), increase strategic flexibility and reduce the risk of conflict (Nooteboom et al., 1997), but they also require more time to implement (Das and Teng, 1998), which can mean product obsolescence in an innovation network. Finally, existing contractual theories (e.g. transaction costs, positive agency, incomplete contracts) mainly suggest two measures of the degree of formalisation in exchanges: the existence of a contract and the number of clauses, as well as the forms of the exchanges (e.g. written and explicit or not).

\footnotetext{
${ }^{1}$ For example, conflict resolution arrangements include joint resolution (informal), persuasion (informal), coercion (informal), sanctions or recourse to a third party (both can be formal or informal, but generally formal and contracted). Moreover, some seemingly informal arrangements are written into contracts.

${ }^{2}$ We acknowledge freely that many other mechanisms (or governance modes) could be studied, especially those of a relational nature, such as common culture, reputation or inclusion in social networks.
} 
Inter-organizational trust. Trust is an underlying psychological condition that may be the cause or result of a specific behaviour (cooperation) or choice (risk) (Woolthuis et al., 2005), though it also has been portrayed as an informal arrangement (Dyer and Singh, 1998; Martinez and Jarillo, 1989) or complement to contracts (Dyer and Singh, 1998; Poppo and Zenger, 2002). Variations in risk and interdependence can affect the degree of trust (Cullen et al., 2000), which in turn has a direct influence on partnership success (Morgan and Hunt, 1994), especially in uncertain environments. For example, in an innovation project setting, trust can induce predictions of network members' behaviour (Ring and Van de Ven, 1994). Because unforeseen events are inherent to innovation networks, it is impossible for contracts to be comprehensive, so some trust must exist. We consider three possible states: trust, mistrust and no trust.

Shared results. An essential element of cooperation is the determination of how outcomes get shared among members. An equitable division (i.e. each member's payoffs are a function of its contribution) can give project members an incentive to work harder, which should improve the overall performance of the innovation project (Kabanoff, 1991). An equal share instead implies that the parties (hub firm and members) each receive the same share of the outcomes, regardless of their investment. Whether planned ex ante or not (an important distinction in positive agency theory), the distribution can be either fair or equal (cf. theory of incomplete contracts).

Guarantees. These mechanisms attempt to prevent opportunistic behaviour (Min-Ping et $a l ., 2009)$ by making it expensive for opportunist members to exit. We distinguish immediate or direct guarantees, which pertain to specific assets, from deferred or indirect guarantees, which instead affect reputations or future business opportunities. Accordingly, this tool can take multiple modes: no guarantees, direct, indirect or a mixture. The direct modes imply immediate reactions to members' behaviours, whereas indirect modes strike a later blow to the opportunist's reputation (Rubin, 1990) or exclude the member from further business 
opportunities. This latter consequence appears very useful as a guarantee, because firms usually join networks specifically to gain business opportunities (Brunetto and Farr-Wharton, 2007).

Conflict resolution. An innovation network contains multiple possible interactions: twoto-two, one-to-several and several-to-several (Gomes-Casseres, 1994). If a conflict arises between technical partners, another member (e.g. hub firm) can intercede to resolve the issue-a notion not previously addressed in network literature. Conflict resolution mechanisms are highly complex in innovation networks and must reflect the heterogeneous levels of network members' commitment. Thus it is difficult to give an ex ante description of a conflict resolution mechanism, and we followed Mohr and Spekman (1994) to select five mechanisms that likely describe multilateral relations in innovation networks: ${ }^{3}$ (1) joint resolution of a problem, such that the parties agree to work together to find a mutual solution; (2) persuasion, which occurs when one party tries to persuade the others that a particular solution is the best outcome; (3) coercion, such that one partner forces others to accept its preferred solution; (4) sanction, in which case a network member is expelled; and (5) introduction of a third party to obtain recourse to arbitration.

In Appendix 1 we summarise these coordination mechanisms and forms, as well as the main theories on which they are based. These coordination mechanisms help reveal the inner workings of inter-organizational relations, especially innovation networks. Prior research has identified the overall potential impact of network dimensions such as hub firm dependence, prior relations and type of conflict, but to the best of our knowledge, no studies address their separate impacts on each mechanism and its implementation.

The influence of dependence, prior relations and conflict type

\footnotetext{
${ }^{3}$ Mohr and Spekman (1994) added domination as a sixth mechanism for bilateral relations. In the multi-lateral relations we study, domination is largely indistinguishable from coercion.
} 
Three inter-partner relation dimensions are critical determinants of which coordination mechanisms are used: dependence (Ambos and Schlegelmilch, 2007), prior relations (Jiang et al., 2008) and conflict type (Das and Teng, 2002) .

Dependence. In an innovation network, partners share scarce resources, which creates dependence. A classic definition notes that the 'dependence of an actor A, on another actor B, as directly proportional to A's motivational investment in goals mediated by $\mathrm{B}$, and inversely proportional to the availability of those goals to A outside of the A-B relation' (Emerson, 1962: 32). Ambos and Schlegelmilch (2007) show that increasing levels of dependence lead to more socialisation and formalisation; other studies (Baliga and Jaeger, 1984; Gencturk and Aulakh, 1995; Gupta and Govindarajan, 1991) report positive relationships between dependence and control. Dependence also influences parties' perception of the benefits they receive (Doz, 1988) and the use of guarantee systems and conflict resolution mechanisms. In dependency situations, partners often resort to coercive and punitive actions (Kumar et al., 1998; Lui et al., 2006), because asymmetric dependency influences inter-firm trust, which is critical to the development of long-term relationships (Kumar et al., 1995). That is, dependency relationships are more dysfunctional and less stable than symmetric relationships, so they make it more difficult to develop trust. A high level of dependence leads to less trust (Kumar et al., 1995), more control (Ambos and Schlegelmilch, 2007), less relationship continuity and less cooperative behaviours.

Prior exchange relations. Innovation networks can include unfamiliar partners or repeated ties with the same partners. With unfamiliar partners, contractual agreements and formal mechanisms serve to deter opportunistic behaviour. The lack of mutual understanding and trust causes partners to feel uncertain about the future (Doz, 1996; Jiang et al., 2008; Ring and Van de Ven, 1994). Prior relations thus can be a valuable asset that enables partners to develop relational capability and capital (Dyer and Singh, 1998). Partners invest in relationship

\footnotetext{
${ }^{4}$ Inter-organizational relations also are affected by other dimensions (e.g. past alliance history, partnership experience, cognitive interpersonal connivance, communication, commitment, type of opportunism). Our purpose is not to develop an exhaustive list (Jiang et al., 2008) but rather to focus on those that appear the most determinant.
} 
building and bear relationship-specific set-up costs (Reuer and Arino, 2007). Familiar partners also develop a good understanding of their partners' procedures, management systems and cultures, which can mitigate ex post coordination, conflict resolution or information-gathering issues that formal contractual provisions otherwise attempt to address (Reuer and Arino, 2007). Relationship-specific knowledge also develops from frequent and intense partner interactions, which can enhance cooperation efficiency (Dyer and Singh, 1998). Regular relations increase mutual trust and reduce the need for contractual safeguards (Gulati, 1995a), so the partners avoid the costs of more complex collaborative agreements (Reuer and Arino, 2007). Gulati (1995b) also shows that more prior alliances lowers the likelihood of subsequent equity-based alliances. However, Goerzen (2007) finds that the propensity to repeat equity-based partnerships has a negative influence on economic performance, particularly in environments marked by technical uncertainty (e.g. innovation networks). Thus prior relations likely lead to commitment and the development of relationship-specific assets, such as mutual knowledge of partners' procedures and values. Repetition over time also creates opportunities for mutual learning that encourage the development of trust (Inkpen and Currall, 2004).

Conflict type. In innovation networks, partners have individual interests that are not necessarily congruent with their partners' (Das and Teng, 2001). Conflicts, which refer to the degree of divergence in partners' preferences, interests and practices (Hardy and Phillips, 1998), arise because of the inherent uncertainty and interdependencies between parties (Mohr and Spekman, 1994). Das and Teng (2002) strongly recommend taking this dimension into account in analyses of cooperation agreements; because conflicts arise for various reasons, their sources affect cooperation in different ways. We consider two main types (Mooney et al., 2007):

- Cognitive conflicts appear when partners disagree about a task. In innovation networks, partners might have different views about the best technical solutions, and to resolve the cognitive conflict, they might exchange ideas during meetings (informal coordination) 
(Amason, 1996). Cognitive conflicts generally improve decision making by fostering more mutual understanding (Mooney et al., 2007);

- Affective conflicts involve personal disagreements, such as power struggles or personal incompatibilities over private interests and opportunistic behaviour. Partners' incompatible goals could lead them to try to maximise their private benefits without furthering common benefits, such as by adopting opportunistic behaviours to appropriate others' tacit knowledge (Das and Teng, 2002). Even with an explicit contract, firms rarely seek legal penalties in response to affective conflicts (Lee and Cavusgil, 2006). Moreover, inter-organizational trust decreases when one partner displays dysfunctional behaviours (Lusch and Brown, 1996; Morgan and Hunt, 1994).

With Appendix 2 we summarise literature pertaining to these dimensions and their effects on the coordination mechanism(s). Accordingly, we derive the theoretical model in Figure 1.

\section{Insert Figure 1 here}

\section{Methods}

Despite research into each coordination mechanism, no studies address the dynamic processes in innovation networks that may affect their implementation or use; therefore, we adopt a qualitative approach to explore these phenomena.

\section{Case selection}

We opted for a qualitative case study methodology to gain a comprehensive, in-depth understanding of which coordination mechanism is best suited to each situation, as defined by hub firm dependence, prior relations and type of conflict, as well as over time. The six case studies constitute a theoretical sample (Glaser and Strauss, 1967); we took great care to select innovation networks of different sizes and in different sectors ${ }^{5}$ (see Table 1) that also share common characteristics (Miles and Huberman, 1994). All the chosen networks focused on

\footnotetext{
5 Most prior innovation network studies feature biotechnology or information technologies (Gilsing and Nooteboom, 2006). We selected cases from other sectors as well.
} 
technological innovation, contained at least three members, were structured around a small hub firm and included members of different sizes, including very large firms (see Appendix 3).

We focus on the hub firms for several reasons. Small and medium-sized enterprises (SMEs) often form links to obtain access to required assets (Hagedoorn and Schakenraad, 1990) and learn new skills (Powell et al., 1996). By taking a central role, the hub firm gains power and influence in the network (Wasserman and Faust, 1994), so the study of its dependence relationships becomes particularly interesting, especially for SMEs. Moreover, innovation networks typically involve high levels of transactional uncertainty and exchanges of tacit knowledge, such that coordination among actors is necessary and difficult. Finally, size asymmetry (e.g. small hub firm and large partners) tends to affect the management of alliance relations and the coordination mechanisms implemented (Oliver, 1990).

\section{Insert Table 1 here}

\section{Data collection and coding}

Fifty-three interviews (see Table 2), conducted between March 2006 and February 2008, included the members of six innovation networks, including project bearers and financial, technical, industrial, commercial and legal members. ${ }^{6}$ They averaged 90 minutes in length. The semi-structured interviews were designed to identify coordination mechanisms implemented by the hub firms, so we first asked informants to describe their project and how they coordinate with others. Next we focused on coordination modes and prepared a map of each network, which informed further interviews. ${ }^{7}$ The maps helped interviewees describe the coordination modes they used with different members. To complement these data, we gathered internal email exchanges between project members; notes made by the hub firm in progress reports, business plans and contracts; and external sources such as Internet and press articles, which offered triangulation in most cases. For each case, we examined a range of relations

\footnotetext{
${ }^{6}$ For confidentiality, we cannot provide the names of the innovation projects. The members-a term that refers to an organization, not an individual — are combined to indicate the mean number per year of observation.

${ }^{7}$ The maps are available on request.
} 
(approximately $100 \operatorname{total}^{8}$ ) between hub firms and network members. For example, in project A, the hub firm contacted 29 technical members: 11 partners and 18 service providers.

\section{Insert Table 2 here}

To code the data from different sources, we used content analysis procedures (Strauss, 1987). First, we coded all data into categories, according to our theoretical model (Yin, 1989), that reflect the five coordination mechanisms and three dimensions. Second, we created subcategories for each mechanism. For example, the conflict resolution subcategories were its five modes: joint resolution, persuasion, coercion, sanction and third-party arbitration. Third, a second researcher recoded a random selection of $15 \%$ of the data (eight interviews). This double coding check ensured consistency in the classification of the verbatim comments.

\section{Results}

In discussing our results regarding the influence of the three dimensions on the five coordination mechanisms, we detail each one and link the findings to theoretical literature.

Degree of formalisation. As we show in Figure 2, none of our innovation networks was composed exclusively of members with which the hub firm had previous relations. Instead, they relied on formal exchanges, such as confidentiality agreements at a minimum, to protect their inventions. The level of dependence influenced the degree of formalisation; informal exchanges arose when the level of dependence was low, because that situation lowered the risk for the hub firm, and informal arrangements reduced any contractual costs. This solution also facilitated exchange flexibility and adaptability for the future development of the innovation project:

If the company with which you work can easily be replaced by another, it is not necessary to sign a partnership agreement. A confidentiality agreement is sufficient. It is long and costly to draw up a partnership contract, especially if you do not posses the required legal competence (Managing director, Transparts)

\footnotetext{
${ }^{8}$ The lack of precision in the number of relations studied reflects the complexity of the topic. Most interviewees referred to a group of members (i.e. technical members) rather than individual firms.
} 
With greater dependence, the hub firm found informal arrangements insufficient and supplemented them with formalised relations. Formal contracting represented its attempts to reduce the risks of opportunistic or defective behaviour:

You can never know for sure how your partner will behave. Signing a contract doesn't mean that you will be fully protected but it will limit the risks. We've been involved in partnerships in the past and I know that partners' objectives can change over the course of the cooperation. The contract will serve as a reminder of their original commitment. This is very important, especially when this partner plays an important role for the project (Managing director, Protect)

The degree of exchange formalisation also changed as interactions developed. A partner that is loyal to the hub firm and shares a common vision of the project encourages the emergence of informal relations; if conflict arises, the degree of formalisation instead increases. Unlike informal discussions, formal exchanges (e.g. contracts, letters, e-mails, written reports) offer tangible evidence of how cooperation evolves, and in a dispute, they provide concrete evidence for a court or arbitrator. However, we did not observe any development from formal to exclusively informal arrangements.

\section{Insert Figure 2 here}

Trust. Hub firms tend to be cautious when they are dependent and have no previous relations with another member. A member with an essential role may be tempted to pursue selfish goals and take advantage of its position to impose its vision to the hub firm. If the hub firm has a less than positive perception of the member's intentions, it needs high expectations of that member's expertise and efficiency (i.e. competence-based trust; Zucker, 1986):

We are well aware that there are significant risks involved when cooperating with such a company, but we don't have much of a choice. I chose these partners because they could really help us for this project. They are highly recognised in their sector (Managing director, Jump)

Without prior relations but also without dependency, other coordination mechanisms arise, such as guarantees, conflict resolution arrangements or exchange formalisation. In this situation, hub 
firms often tested how members behave. If the member reaches the objectives set by the hub firm and demonstrates high commitment to the project, trust can develop. For example, a provider in the Motorisation network agreed to execute additional tasks requested by the hub firm, leading to enhanced trust between them:

This is a very nice project and I think it will be a big success. It is interesting for me to be associated with this project because I can learn a lot and it also highlights our knowledge. Currently, we are just providers; but by showing the hub firm how we can contribute to the project, we hope to become a partner. We must therefore adopt an exemplary behaviour (Engineer, Motorisation)

As Figure 3 indicates, when all runs smoothly in the project, trust develops; if not, mistrust emerges. In an exchange, it is possible for trust and mistrust to alternate. For example, unfulfilled commitments in the Transparts network turned trust into mistrust. If the conflicts related to cooperation are not resolved, the hub firm may even consider the member an enemy to confront (i.e. win-lose game). ${ }^{9}$

\section{Insert Figure 3 here}

Shared results. The distribution of outcomes, generally agreed on ex ante, was equitable in most cases, as we show in Figure 4. This division existed even when the hub firm was dependent or had no previous relation with the member. The consensus objective was to encourage members' involvement:

If you want to work with a company like PSA Peugeot Citroen, it is necessary for its percentage of retribution to be equivalent to its input, otherwise you can just dream that they'll work with you (Managing director, Motorisation)

Yet the intangibility of certain resources prevents precise assessments of members' contributions, so other allocation methods are difficult to implement. Distribution rules are not static but instead get renegotiated with changes in the hub firm's level of dependence and trust, particularly as cooperative experience with another member increases. For example, with its

\footnotetext{
${ }^{9}$ Our configurations only include arrangements by the hub firm that favoured progress for the innovative project.
} 
industrial provider, the hub firm in the Pinc\&pile network shared outcomes proportional to financial commitments. As trust increased, the division grew more balanced, though without ever becoming equal. Transitions from an equal to an equitable division also occurred when the partner's level of commitment was less important than initially anticipated (e.g. Telescopic network). A lack of involvement may relate to free-riding behaviour (e.g. Transparts) or changes in the resources and skills required for the project. However, when equal distribution did not appear at the start, it was never introduced later, usually to avoid potential conflicts stemming from perceptions of injustice by members who had been involved from the beginning:

You cannot treat a partner who's been with the project since its beginning in the same way as a partner who came on board later on. It would be unfair because the risks taken by a partner decrease with the progress of the project. Consequently, recent partners cannot receive the same part of the results (Managing director, Telescopic)

Nor was there any evolution toward an egalitarian distribution, for similar reasons; initial members would not have understood this privilege, increasing the risk of conflict.

\section{Insert Figure 4 here}

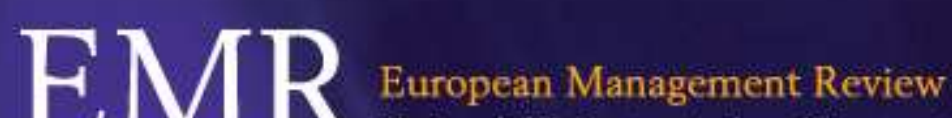

For security reasons, your session will time out in 10 minutes (at 12:52 PM,

9:52 AM GMT). Please save your work to avoid potential loss. To refresh your

session, close this message and save your work or return to your main menu. You

may then continue working as normal. 


\section{Submit a Revision} Review the information below for correctness and mak
CLICK 'SUBMIT' to complete your submission.

$\square$ View and

Respond

to

\section{Decision}

Letter

Type,

Title, \&

Abstract

Attributes

Authors \&

Institutions

Details \&

Comments

File

Upload

Review \&

Submit
Step 1:View and Respond to Decision Letter

Response to Decision Letter:

Dear Editor in Chief

We are very pleased to send you the revised version of our manuscript. As you will see, it has been entirely rewritten to make the phraseology and writing in accordance to EMR standards.

For this purpose, we have worked in close relationship with Elisabeth Neviss Caswell, recommended by Serenna Giovannoni, and we would like to thank Serenna again for this advise, and Elisabeth for her fantastic work.

Finally, we thank you and the reviewers for the very constructive comments during the revision process.

Sincerely Yours

Caroline and Elodie
Step 2: Type, Title, \& Abstract

Manuscript Original Article

Type:

The dynamics of coordination in innovation networks

Title:

Running

Head:

Abstract:

Despite abundant literature dedicated to networks and coordination, few empirical studies address the internal operations of inter-organizational networks. This research therefore aims to characterise coordination mechanisms of various forms and analyse their evolution through an empirical analysis of six innovation networks. Three main dimensions determine the type of coordination adopted by a hub firm: its dependency, prior business relations, and type of conflict. The study also reveals a negative effect of a singular reliance on trust. Indirect guarantees need to combine with direct guarantees to facilitate hub firm dependence. Moreover, the coordination modes and the use of hard conflict resolution mechanisms vary with the type of conflict (i.e., project or behavioural). These findings have key implications for research and practice. 
Step 1:View and Respond to Decision Letter

Response to Dear Editor in Chief

Decision Letter:

We are very pleased to send you the revised version of our manuscript. As you will see, it has been entirely rewritten to make the phraseology and writing in accordance to EMR standards.

For this purpose, we have worked in close relationship with Elisabeth Neviss Caswell, recommended by Serenna Giovannoni, and we would like to thank Serenna again for this advise, and Elisabeth for her fantastic work.

Finally, we thank you and the reviewers for the very constructive comments during the revision process.

Sincerely Yours

Caroline and Elodie

\section{Step 2: Type, Title, \& Abstract}

Manuscript Original Article

Type:

Title: $\quad$ The dynamics of coordination in innovation networks

Running The dynamics of coordination

Abstract:

Despite abundant literature dedicated to networks and coordination, few empirical studies address the internal operations of inter-organizational networks. This research therefore aims to characterise coordination mechanisms of various forms

and analyse their evolution through an empirical analysis of six innovation networks. Three main dimensions determine

the type of coordination adopted by a hub firm: its dependency, prior business relations, and type of conflict. The study

also reveals a negative effect of a singular reliance on trust. Indirect guarantees need to combine with direct guarantees to

facilitate hub firm dependence. Moreover, the coordination modes and the use of hard conflict resolution mechanisms vary

with the type of conflict (i.e., project or behavioural). These findings have key implications for research and practice.

Step 3: Attributes

Keywords: technological innovations, RandD, case research, Networks

Additional Keywords:

1. gardet, elodie; University of Savoie, IREGE

2. mothe, caroline; University of Savoie, IREGE

Dear Editor

We are pleased to send you our revised manuscript on the dynamics of coordination modes in innovation networks Thank you so much again for recommending us to work with your "most reliable copyeditor" (as Serenna said) 
mbining direct and indirect guarantees, as Figure 5 shows. The hub firms used safeguards to prevent opportunistic behaviours or exit by members that were critical to the project:

In the contract we specified that the company was to invest in specialised machinery and that we would pay them three months after delivery. So if any problems arose we would have time to identify them and to react. There were also penalties for late deliveries (Managing director, Jump)

Without prior knowledge of the member, the hub firm turned to direct guarantees. For example, in the Motorisation network, a technical partner was required to purchase a highly specialised machine to test certain parts; the machine could not test other types of parts and thus represented a direct guarantee for the hub firm. Indirect guarantees, mostly based on potential reputation damage, also were available, though only when the hub firm was dependent and had cooperated successfully in the past with the member. The hub firm in the Telescopic case was dependent on its commercial partner and protected itself only through indirect guarantees. It was not in a position to act when the member was bought by another firm and left the project:

This partner did not provide sufficient guarantees. It is a large firm and I was not in a position to negotiate. However, I will not proceed like that next time because it is too much of a risk: without this type of firm it is not possible to continue with my innovation project (Managing director, Telescopic)

In the Jump project, the hub firm could affect the reputation of members with which it had close ties; thus, it used only indirect guarantees with one technical partner that offered commonly available, easily substitutable competencies and with which it had previous positive relations.

The types of guarantee change in the case of conflict or when hub firms reduce their dependence (e.g. Jump and the purchase of specialised machinery). If conflict resulted from opportunistic behaviour by a partner, indirect guarantees were backed by direct guarantees:

At the start I did not require many guarantees from this technical member because they were not essential to the project. But we had some trouble with them, so we decided to add a clause to the contract to include a penalty for late delivery (Managing director, Motorisation) 
In the Transparts case, the hub firm noted its past relation with its commercial partner and its low degree of dependency and therefore opted for relations based on trust, informal exchanges and indirect guarantees. When that partner filed a complementary patent though (for powders, whereas the hub firm's patent covered solids and liquids), it implemented new guarantee procedures and grant back clauses, ${ }^{10}$ stipulating that the firm had the right to use any innovation introduced by members during the project. Conversely, despite any emergence of trust, direct guarantees generally were included in the original contract and could not be replaced completely by indirect guarantees.

\section{Insert Figure 5 here}

Conflict resolution. When a conflict situation arose, as can occur at any time in an innovation project, the hub firm took resolution measures that reflected its degree of dependence and the type of conflict, whether cognitive or affective (see Figure 6).

First, if the conflict related to the project and the hub firm was not dependent, the hub firms all communicated with their partners to resolve conflicts, that is, to "calmly solve them through dialogue.' If any issues remained unresolved through discussion, the hub firms attempted to persuade other members to adopt their own choices. Only if this solution failed to satisfy all members would it lead to a loss of motivation and thus the risk of opportunistic behaviour.

Second, when conflict related to the project but the hub firm was dependent, its patents could not guarantee that the hub firm had bargaining power, so the persuasion flows reversed, from member to hub firm. The influential member would convince the hub firm to adopt a solution favourable to its own interests. For example, in the Jump project, the technical partner chose the materials that best served its interest.

\footnotetext{
${ }^{10}$ A grant back clause is a 'provision in a licensing agreement under which the licensee is required to disclose and transfer all improvements made (including related know-how acquired) in the licensed technology during the licensing period' (http://www.businessdictionary.com/definition/grant-back-clause.html).
} 
Third, for cooperation conflict with a non-dependent hub firm, such that the partner displays minimal commitment and acts opportunistically, the hub firm generally prefers exit by the member, because it can select another partner. This sanction is faster than engaging in lengthy discussions, which could affect the project's progress. Replacing a member also is no more expensive than rebuilding a relation destroyed by treachery.

Fourth, when the hub firm was dependent and faced conflict linked to cooperation, it used coercion or a third party to resolve the conflict. Its dependence means the hub firm must rely on still other members; together, they all force the defaulting member to surrender. In addition, it may also appeal to an arbitrator, if this route has been specified in the contract. Otherwise, it would appeal to the courts and allow a third-party judge to settle the dispute. Such arrangements leave little hope of reviving cooperation, as both the Pinc\&pile and Transparts cases showed. In both cases, the defaulting member exited, but the procedure entailed two challenges: It is long-legal proceedings can even exceed the duration of the project—and it is costly, especially for small firms. However in some cases, the hub firm must turn to this method because the contract did not contain an arbitration clause or the conflict involved betrayal.

\section{Insert Figure 6 here}

\section{Discussion}

Whereas previous work on innovation networks has focused on one or two coordination modes and used a static approach, we adopt a more integrative and dynamic perspective to analyse how hub firms coordinate their networks.

\section{Risk of low formalisation}

Trust as a complement to formal mechanisms. By accounting for the role of dependence and the potentially negative influence of prior relations, this study adds nuance to the debate about the relationship between contracts and trust (Poppo and Zenger, 2002). A widespread assumption holds that trust correlates positively with successful cooperation and, though it may fluctuate (Ring and Van de Ven, 1994), generally increases the level of partner satisfaction (Lei 
and Slocum, 1992). However, this study shows that it also can turn into mistrust, such that trust and mistrust are endpoints on a continuum (Lewicki et al., 1998). The level of trust needed between members is difficult to determine (Hamel, 1991) and maintain: Either too much or too little trust leads to poor resource and skill transfers (De Wever et al., 2005), which have significant consequences for both the project and the hub firm. Some authors (Gao et al., 2005; Kumar et al. 1995) consider this question as a function of the degree of dependence between members. Although trust strengthens the level of commitment (Cullen et al., 2000), which might intensify the degree of dependence (Das and Teng, 2001), our case studies reveal that the degree of dependence is secondary. Instead, previous business relations play a more important role for promoting trust (Goerzen, 2007; Gulati, 1995b). As do Dyer and Singh (1998), we have observed that prior successful relations facilitate trust. In all six cases, trust and formalisation are not systematically linked.

In this sense, we consider two streams of literature. First, challenges to the excessive use of transactional modes lead to calls to use socio-cognitive modes such as trust instead (Nooteboom et al., 1997; Woolthuis et al., 2005). In this case, trust represents an informal arrangement, though some authors also maintain its complementary nature with contractual arrangements (Dyer and Singh, 1998; Martinez and Jarillo, 1989; Poppo and Zenger, 2002). Second, trust appears as a coordination mode, complementary to exchange formalisation (Langfield-Smith and Smith, 2003). Thus it could be a specific mode of control (Inkpen and Currall, 2004) or a contextual variable that influences the level of formalisation (Das and Teng, 1998; Ring and Van de Ven, 1994).

Our study reveals trust as complementary to and not substitutable with formal coordination modes. Establishing an exchange relationship based solely on trust could prove dangerous (e.g. Pinc\&pile, Transparts), leading to wasted time and weak motivation. Furthermore, a detailed contract does not appear detrimental to cordial behaviour or trust (Lee and Cavusgil, 2006), contrary to the idea that high formalisation destroys trust or exacerbates 
conflicts (Nooteboom et al., 1997; Woolthuis et al., 2005). In the six innovation networks we studied, contracts instead facilitate trust, because drawing up the contract required frequent exchanges. This lengthy negotiation phase offered members an opportunity to communicate, get to know one another, and express their motivations and objectives.

Perhaps our results reflect the relatively small size of all six hub firms. Research with a relational perspective (e.g. Dyer and Singh, 1998; Gulati, 1995a) suggests a de-emphasis on contracts, such that partners switch from contractual to relational coordination, when there is a high level of goodwill trust and mutual expectations of reciprocity (Zucker, 1986). Our results offer a different perspective: We found no evidence that positive goodwill trust dynamics reduce the importance of contracts. Rather, trust clearly is a complement to formal modes. Thus,

Proposition 1a: In an innovation network with a small hub firm, a sole reliance on trust, even if prior relationships have been successful, has negative consequences.

Our results challenge the role of trust as the social glue that keeps members together (Faems $e t$ al., 2008). Unlike previous research that suggests that poor goodwill trust contributes to partnership dissolution (Arino and de la Torre, 1998; Doz, 1996), we observe no such effects. In the Jump and Protect projects for example, regardless of their negative goodwill trust dynamics, the partners negotiated new contracts involving the same members. Hub firms explained their decision by describing their technological dependence on a competent partner that could ensure project success (Faems et al., 2008). These findings suggest that competence trust (Nooteboom 2007; Zucker, 1986), or a belief in the partner's ability to meet expectations, might be more important than goodwill trust. Thus, we propose:

Proposition 1b: In an innovation network, relying on competence trust benefits the project more than relying on goodwill trust.

Insufficient indirect guarantees. The guarantees we found were not limited to financial guarantees but also extended to specialised assets and brand image. In uncertain environments, 
such assets modify the degree of interdependence (Thomke and Kuemmerle, 2002). By forcing a member to invest in specific assets, the hub firm can increase the member's dependency while decreasing its own (Dyer and Singh, 1998). Using its central position within the network, the hub firm also can influence members' reputations and future business opportunities. The more dependent the hub firm, the more it tended to protect itself using a combination of direct and indirect guarantees. If the partner brought key resources to the project, guarantees tended to include both investments in specific machines or financial delay penalties and threats of reduced future business opportunities; the hub firm's main objective was to minimise the risk of partner exit. We thus confirm the need for multiple guarantees in non-recurrent transactions:

Proposition 1c: In an innovation network with a highly dependent hub firm, a combination of direct and indirect guarantees can advance the project.

\section{Sense of justice in equitable distribution}

The equitable distribution of outcomes is more effective for curbing opportunistic behaviour (Das and Teng, 1998; Gulati, 1995b), because it binds members to the hub firm and network. A member probably will not risk jeopardising its relationship by exploiting the hub firm's specific investments if it has an equal stake in the project (Das and Rahman, 2010). Before launching the project, the members agree on the returns they will receive, and an equitable distribution appears to be the preferred solution (Jap, 2001), especially in innovation networks characterised by high uncertainty. Equity also offers a means to legitimise the resource allocation, because the issue of fairness persists throughout the project's lifecycle, particularly because the sense of distributive justice is critical in innovation networks. Equitable distribution as an incentive can promote project performance (Jap, 2001; Kabanoff, 1991). An opportunistic member cannot expect cooperation from the hub firm in its withdrawal process and will find it difficult to recover its equity stake. That is, 'The value of the tied-up equity that an opportunistic partner risks losing would raise the required threshold of economic gains from opportunism' (Das and Rahman, 2010: 64). Thus: 
Proposition 2: In innovation networks, equity distribution decreases the risk of partner opportunism and advances the project.

\section{Compromise in conflict resolution}

Conflict resolution modes vary with the degree of dependence and type of conflict. For Kozan et al. (2006), the way to manage conflict depends on the level of investment made by the parties to the exchange, which can be linked to the level of dependence, regardless of the type of conflict. However, the type of conflict also has a major impact. For example, in our case studies, if the conflict related to the project, the conflict resolution mechanism proceeded along the five mechanisms, as theorised in prior research: Members started by negotiating before turning to harsher techniques (Mohr and Spekman, 1994) such as coercion or sanction. However, this prediction was not supported when the conflict related to the cooperation itself (e.g. Pinc\&pile), in which case the hub firm used the most drastic solutions available and took the partner to court. Thus:

Proposition 3a: In innovation networks, hard conflict resolution mechanisms are better suited to conflicts related to cooperative dimensions.

Tuten and Urban (2001) also extend Mohr and Spekman's (1994) model to include the previous relations as a potential moderating variable; they posit that resolution methods are softer when partners previously have been in a long-term relationship. In our innovation networks, previous relationships did not have a significant effect on conflict resolution mechanisms though. In both cases that featured hard conflict resolutions, the hub firm had an existing, long-term partnership with the members. The type of conflict and degree of dependency seemed to have more influence on the resolution mechanism used:

Proposition 3b: In innovation networks, hard conflict resolution mechanisms are better suited to conflicts including a hub firm with a low level of dependency 
Finally, conflicts erode trust and reduce employee satisfaction, which tends to delay the project and undermine the level of commitment to the relationship (Cullen et al., 1995). The complexity of these emotionally charged phenomena is difficult to grasp just with contractual theories, which offer only two conflict resolutions: revocation (exit) or court. In reality, our case studies show that other mechanisms, such as joint resolution, are common, provided that each party accepts the dialogue or persuasion techniques. If a conflict arises between a hub firm and a technical partner, the hub firm may call on another technical member to lead the focal partner in the desired direction (Motorisation). Such a situation has not been considered in prior literature, which instead usually focuses on bilateral relations (Mohr and Spekman, 1994). We offer:

Proposition 3c: In innovation networks, the use of another network member as an arbitrator can facilitate conflict resolution.

\section{Conclusion}

This in-depth study reveals several aspects of innovation networks that previously have remained unstudied. We investigate the impact of three dimensions (hub firm dependence, previous business relations, type of conflict) on five coordination mechanisms. The degree of formalisation and trust vary depending on the existence of previous positive relationships; the distribution of outcomes and guarantees instead vary with the hub firm's level of dependence. Our results offer additional knowledge about not only these five coordination mechanisms but also their different forms and how they develop during the course of the innovation project. We suggest several generalisations of these results.

1. Exchange formalisation. Contracts are inherently incomplete in innovation networks. Extending incomplete contract theory (Grossman and Hart, 1986), we find that it is not always beneficial to draw up a more exhaustive contract; beyond a certain point, the marginal cost of adding clauses increases beyond the benefits. Instead, informal exchanges are appropriate when the level of dependence was low, because the level of risk for the hub firm is limited. 
2. Trust and formalisation. In our case studies, trust and contractual arrangements are complementary, not substitutes for each other.

3. Guarantees. Reputation provides a common tool, perhaps due to the small size of the hub firms in our sample, to threaten damage to a defaulting or opportunistic member.

4. Conflict resolution. Literature on inter-organizational cooperation suggests that discussion leads to cooperation. In innovation networks, this solution works only if all members are satisfied; otherwise, it can harm the project by creating delays and frustration. Conflict literature also identifies neglect as a possible solution (Turnley and Feldman, 1999). In innovation networks, especially during development phases that face major time constraints, this practice did not emerge, despite its apparent frequency in other settings (e.g. franchise relations).

Research implications also emerge from these theoretical discussions. Unlike other forms of cooperation (e.g. R\&D consortia, exploration partnerships), innovation networks resort almost exclusively equitable distribution, though the distribution varied somewhat according to the nature of the innovation being undertaken. In our cases, patents already had been filed; in more fundamental research projects, the resources and contributions of each member would be more difficult to define precisely (Gilsing and Nooteboom, 2006). It would be interesting to analyse whether guarantee mechanisms differ in innovation networks that include competitors (i.e. coopetition). Reputation threats or cultural integration could play much more important roles, because competitors operate in the same economic environment and are often culturally close. Finally, testing our propositions in a sample that includes both small and large hub firms could reveal the coordination mechanisms that are unique to SMEs.

Our results have managerial implications as well, especially in terms of how hub firms select coordination mechanisms. Their degree of dependency and experience in previous positive relationships with the network members should lead hub firms to pursue a strategic combination of the coordination mechanisms. They also should allow for evolution in their 
tactics as conflicts arise and the project progresses. Our study offers a practical way to manage such innovation networks. Hub firms, especially small ones, should be very careful when implementing coordination modes to stabilise their network and promote project success.

Finally, our study suffers from several limitations. First, we analysed a specific context in which the hub firm had registered the patent(s). These hub firms were all European, and it may not be possible to generalise the results to other hub firms, especially in other countries with different intellectual property laws and cooperation mechanisms. Second, we did not address the intensity of the innovation. The degree of uncertainty in the network increases with the degree of novelty, so coordination mechanisms likely vary according to the type of innovation. Third, we analysed only the hub firm's degree of dependence, without studying the degree of dependence of other members. Further research should note dependence throughout the network to shed further light on these aspects. Quantitative studies also could use more refined Likert scales to measure coordination mechanisms and the degree of dependence.

Along with these extensions, further research should recognise that coordination mechanisms appear in other types of networks too (e.g. clusters, R\&D consortia), so a comparison of the different forms of cooperation could provide additional insights into the coordination mechanisms that underlie each form. Such investigation could verify the relevance of the mechanisms in heterogeneous contexts. Some forms might develop in less uncertain environments or settings with low strategic stakes; they also might vary according to the type of financing. We call for research that studies whether the mechanisms shift with the presence of multiple hub firms (e.g. architect, lead operator and caretaker). Other dimensions that may influence the coordination mechanisms include the hub firm leader's personality and/or personal networks, which support the maintenance of a reasonably varied, large pool of potential members eligible for more tightly coupled, action-oriented networks (Grandori and Soda, 1995). Finally, research could note the structural properties of innovation networks and thus add to understanding of density or connectivity in innovation networks-properties that likely affect 
the development of trust and conflict levels. ${ }^{11}$ We thus hope research continues to explicate the way innovation networks can be coordinated.

\section{References}

Ahuja, G. 2000. "Collaboration networks, structural holes, and innovation: A longitudinal study”. Administrative Science Quarterly, 45: 425-455.

Amason, A.C. 1996. "Distinguishing the effects of functional and dysfunctional Conflict on strategic decision making: Resolving a paradox for top management teams". Academy of Management Journal, 39: 123-148.

Ambos, B. and B.B. Schlegelmilch 2007. "Innovation and control in the multinational firm: A comparison of political and contingency approaches". Strategic Management Journal, 28: 473-486.

Arino, A. and J. De La Torre 1998. "Learning from Failure: Towards an Evolutionary model of cooperative venture". Organization Science, 9(3): 306-325.

Baliga, B.R. and A.M. Jaeger 1984. "Multinational corporations: control systems and delegation issues". Journal of International Business Studies, 15(2): 25-40.

Batterink, M.H., E.F.M. Wubben, L. Klerkx and S.W.F. Omta 2010. "Orchestrating innovation networks: The case of innovation brokers in the agri-food sector". Entrepreneurship and Regional Development, 22(1): 47-76.

Brousseau, E. 2000. "What institutions to organize electronic commerce? Private institutions and the organization of markets". Economics of Innovation and New Technology, 9: 245273.

Brunetto, Y. and R. Farr-Wharton 2007. "The Moderating Role of Trust in Sme Owner/Managers' Decision-Making About Collaboration”. Journal of Small Business Management, 45(3), 362-387.Cullen, J.B., J.L. Johnson and T. Sakano 1995. "Japanese

\footnotetext{
${ }^{11}$ We thank an anonymous reviewer for this suggestion.
} 
and local partner commitment to IJVs: Psychological consequences of outcomes and investments in the IJV relationship". Journal of International Business Studies, 26: 91-115.

Cullen, J.B., J.L. Johnson and T. Sakano 2000. "Success through commitment and trust: the soft side of strategic alliance formation". Journal of World Business, 35: 223-241.

Das, T.K. and B.S. Teng 1998. "Between trust and control: Developing confidence in partner cooperation in alliances". Academy of Management Review, 23: 491-512.

Das, T.K. and B.S. Teng 2001. "Trust, control and risk in strategic alliances: An integrated framework". Organization Studies, 22: 251-283.

Das, T.K. and B.S. Teng 2002. "The dynamics of alliance conditions in the alliance development process”. Journal of Management Studies, 39: 725-46.

Das, T.K. and N. Rahman 2010. "Determinants of Partner Opportunism in Strategic Alliances: A Conceptual Framework”. Journal of Business and Psychology, 25(1): 55-74.

De Wever S, Martens $\mathbf{R}$ and K. Vandenbempt 2005. "The impact of trust on strategic resource acquisition through interorganizational networks: Towards a conceptual model”. Human Relations, 58: 1523-1543.

Dhanaraj, C. and A. Parkhe 2006. "Orchestrating innovation networks". Academy of Management Review, 31: 659-662.

Doz, Y. 1988. “Technology partnership between larger and smaller firms". International Studies of Management and Organization, 17: 31-57.

Doz, Y. 1996. "The evolution of cooperation in strategic alliances: Initial conditions or learning processes?”. Strategic Management Journal, 17: 55-83. 
Doz, Y.L., P.M Olk and P.S. Ring 2000. "Formation processes of R\&D consortia: Which path to take: Where does it lead?". Strategic Management Journal, 21(3): 239-266.

Drewello, H., B. Soete and U.G. Wurzel 2002. "Innovation networks in eastern Germany-A still under-utilized potential for human capital formation in the region". Economic Bulletin, Berlin, 39(6): 203-208.

Dyer, J.H. and H. Singh 1998. "The relational view: Cooperative strategy and sources of interorganizational competitive strategy". Academy of Management Review, 23: 660-679.

Emerson, R.M. 1962. "Power-dependence relations". American Sociological Review, 27: 3141.

Faems, D., M. Janssens, A. Madhok and B. Van Looy 2008. "Towards an integrative perspective on alliance governance: Connecting contract design, contract application and trust dynamics". Academy of Management Journal, 51: 1053-1078.

Gao, T., J.M. Sirgy and M.M. Bird 2005. "Reducing buyer decision-making uncertainty in organizational purchasing: Can supplier trust, commitment, and dependence help?", Journal of Business Research, 58(4): 397-405.

Gencturk, E.F. and P.S. Aulakh 1995. "The use of process and output controls in foreign markets”. Journal of International Business Studies, 26: 755-786.

Gilsing, V. and B. Nooteboom 2006. "Exploration and exploitation in innovation systems: The case of pharmaceutical biotechnology". Research Policy, 35: 1-23.

Glaser, B.G. and A.L. Strauss 1967. The Discovery of Grounded Theory: Strategies for Qualitative Research. Chicago: Aldine.

Goerzen, A. 2007. "Alliance networks and firm performance: the impact of repeated partnerships". Strategic Management Journal, 28: 487-509.

Gomes-Casseres, B. 1994. "Group versus group: How alliance networks compete". Harvard Business Review, July-August: 4-11. 
Grandori, A. and G. Soda 1995. "Inter-firm networks: Antecedents, mechanisms and forms". Organization Studies, 16(2): 183-214.

Grossman, S.J. and O.D. Hart 1986. "The costs and benefits of ownership: A theory of vertical integration”. Journal of Political Economy, 94: 691-719.

Gulati, R. 1995a. "Social structure and alliances formation patterns: a longitudinal analysis". Administrative Science Quarterly, 40: 619-652.

Gulati, R. 1995b. "Does familiarity breed trust? The implications of repeated ties for contractual choice in alliances”. Academy of Management Journal, 38(1): 85-112.

Gupta, A. and V. Govindarajan 1984. "Business unit strategy, managerial characteristics, and business unit effectiveness at strategy implementation". Academy of Management Journal, 27: $25-41$.

Hamel, G. 1991. "Competition for competence and interpartner learning within international strategic alliances”. Strategic Management Journal, 12: 83-104.

Hardy, C. and N. Phillips 1998. "Strategies of engagement: Lessons from the critical examination of collaboration and conflict in an interorganizational domain". Organization Science, 9: 217-230.

Inkpen, A.C. and S.C. Currall 2004. "The coevolution of trust, control, and learning in joint ventures”. Organization Science, 15: 586-599.

Jap S.D. (2001). "Pie sharing in complex collaboration contexts", Journal of Marketing Research, 38(1): 1547-7193.

Jiang, X., S. Gao and Y. Li 2008. "How trust, dependence and prior ties influence the stability of alliances”. Journal of General Management, 34: 1-17.

Kabanoff, B. 1991. "Equity, equality, power and conflict". Academy of Management Review, 16: $416-441$.

Klein, B. 1980. “Transaction costs determinants of unfair contractual arrangements”. American Economic Review, 70: 356-362. 
Kozan, M.K., S.N. Wasti and A. Kuman 2006. "Management of buyer-supplier conflict: The case of the Turkish automotive industry". Journal of Business Research, 59: 662-670.

Kumar, N., L. Scheer and J.B. Steenkamp 1995. "The effects of perceived interdependence on dealer attitudes". Journal of Marketing Research, 32: 348-356.

Kumar, N., L. Scheer and J.B. Steenkamp 1998. "Interdependence, punitive capability and the reciprocation of punitive actions in channel relationships". Journal of Marketing Research, 35: 225-35.

Langfield-Smith, K., and D. Smith 2003. "Management control systems and trust in outsourcing relationships". Management Accounting Research, 14(3): 281-307.

Lee, Y. and T. Cavusgil 2006. "Enhancing alliance performance: The effects of contractualbased versus relational-based governance". Journal of Business Research, 59: 896-905.

Lei, D. and J.W. Slocum 1992. "Global strategy, competence-building and strategic alliances". California Management Review, 35(1): 81-97.

Lewicki, R.J., D.J. MacAllister and R.J. Bies 1998 “Trust and distrust: New relationships and realities". Academy of Management Review, 23: 438-459.

Lui, S.S., H.Y. Ngo and A.H.Y. Hon 2006. "Coercive strategy in interfirm cooperation: Mediating roles of interpersonal and interorganizational trust". Marketing Management Journal, 16(1): 125-137.

Lusch, R.F. and J.R. Brown 1996. "Interdependency, contracting and relational behaviour in marketing channels". Journal of Marketing, 60(4): 19-38.

Martinez, J.I. and J.C. Jarillo 1989. "The evolution of research on coordination mechanisms in multinational corporations”. Journal of International Business Studies, 20: 489-514.

Mesquita, L.F. 2007. "Starting over when the bickering never ends: Rebuilding aggregate trust among clustered firms through trust facilitators". Academy of Management Review, 32(1): 72-91. 
Miles, M.B. and A.M. Huberman 1994. Qualitative Data Analysis: An Expanded Sourcebook (2nd ed.). Newbury Park, CA: Sage.

Min-Ping, K., J.T. Mahoney and D. Tan 2009. "Why Firms Make Unilateral Investments Specific to Other Firms: The Case of Oem Suppliers”. Strategic Management Journal, 30(2): 117-135.

Mohr, J. and R. Spekman 1994 "Characteristics of partnership success: Partnership attributes, communication behavior, and conflict resolution techniques". Strategic Management Journal, 15(2): 135-152.

Mooney, A.C., P.J. Holahan and A.C. Amason 2007. "Don't take it personally: Exploring cognitive conflict as a mediator of affective conflict". Journal of Management Studies, 44 : 733-758.

Morgan, R.M. and S.D. Hunt 1994. "The commitment-trust theory of relationship marketing". Journal of Marketing, 58(3): 20-38.

Nooteboom, B. 2007. "Methodological interactionism: Theory and application to the firm and to the building of trust". The Review of Austrian Economics, 20(2): 137-153.

Nooteboom, B., H. Berger and N.G. Noorderhaven 1997. "Effects of trust and governance on relational risk". Academy of Management Journal, 40: 308-338.

Oliver, C. 1990. "Determinants of interorganizational relations: Integration and future directions". Academy of Management Review, 15: 241-265.

Pfeffer, J. and G. Salancik 1978. The External Control of Organizations, Harper and Row Publishers, New York.

Poppo, L. and T.R. Zenger 2002. "Do formal contracts and relational governance function as substitutes or complements?”. Strategic Management Journal, 23: 707-725.

Powell, W.W., K.W. Koput and L. Smith-Doerr 1996. "Interorganizational collaboration and the locus of innovation: Networks of learning in biotechnology". Administrative Science Quarterly, 41: 116-145. 
Reuer, J. and A. Arino 2007. "Strategic alliance contracts: Dimensions and determinants of contractual complexity”. Strategic Management Journal, 28: 313-330.

Ring, P.S. and A.H. Van de Ven 1994. "Developmental process of cooperative interorganizational relations”. Academy of Management Review, 19(1): 90-118.

Rubin, P.H. 1990. Managing Business Transactions, Controlling the Cost of Coordinating, Communicating and Decision Making, The Free Press, New York.

Strauss, A. 1987. Qualitative Research for Social Scientists. Cambridge: Cambridge University Press.

Thomke, S. and W. Kuemmerle 2002. "Asset accumulation, interdependence and technological change: evidence from pharmaceutical drug discovery". Strategic Management Journal, 23(7), 619-635.

Turnley, W. and D. Feldman 1999. “The impact of psychological contract violations on exit, voice, loyalty, and neglect”. Human Relations, 52: 895-922.

Tuten, T.L. and D.J. Urban 2001. "An expanded model of business-to-business partnership formation and success”. Industrial Marketing Management, 30(2): 149-164.

Wasserman, S. and K. Faust 1994. Social Network Analysis. Cambridge: Cambridge University Press.

Winch, G.M. and R. Courtney 2007. "The organization of innovation brokers: An international review". Technology analysis \& strategic management, 19: 747-763.

Woolthuis, K., R.B. Hillebrand and B. Nooteboom 2005. "Trust, control and relationship development”. Organization Studies, 26: 813-840.

Yin, R.K. 1989. Case Study Research: Design and Methods. Newbury Park, CA: Sage.

Zucker L. (1986), "Production of trust: Institutional sources of economic structure: 18401920”, Research in Organization Behaviour, 8, 53-111. 
Figure 1 Theoretical model of coordination mechanisms

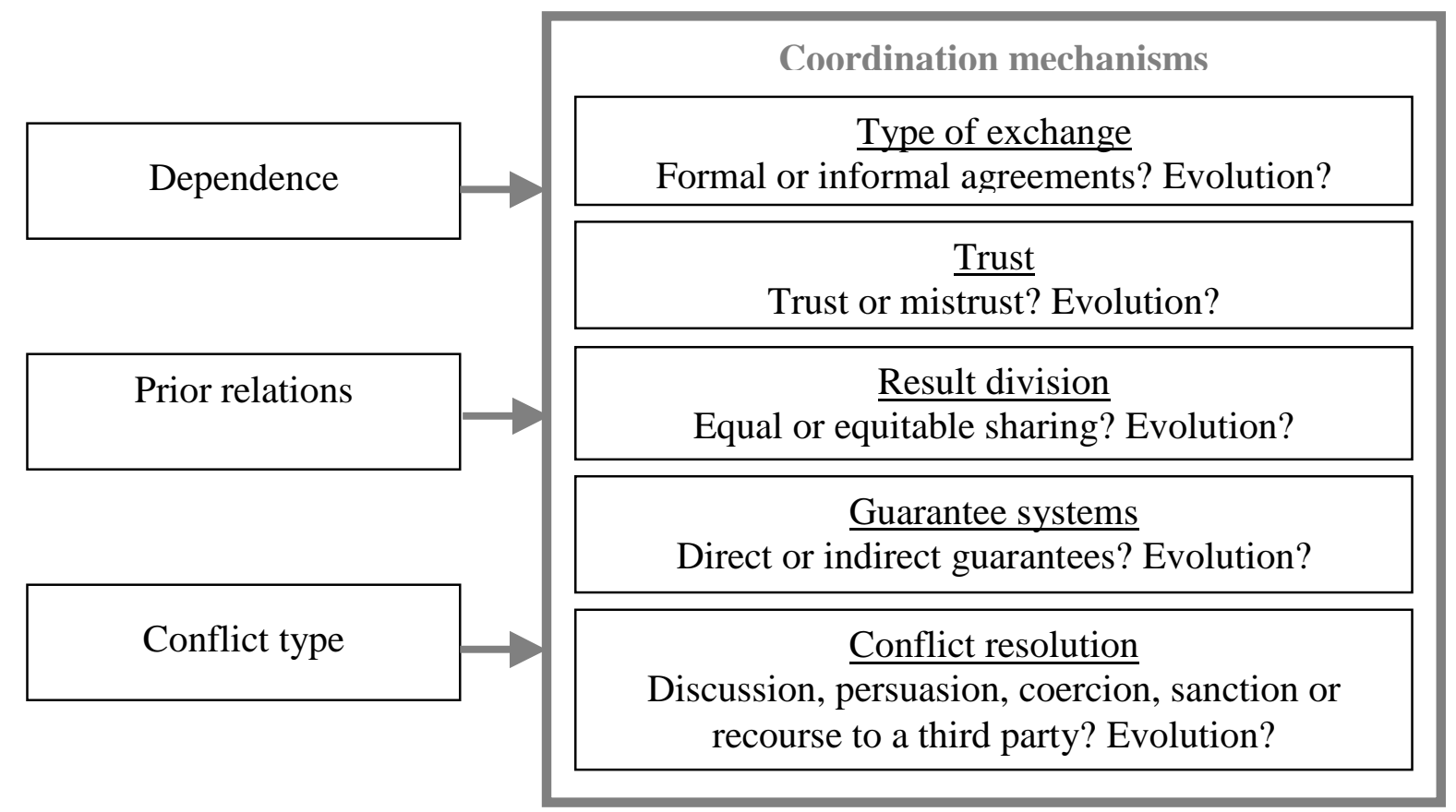

Figure 2 (Re)Defining the degree of formalisation

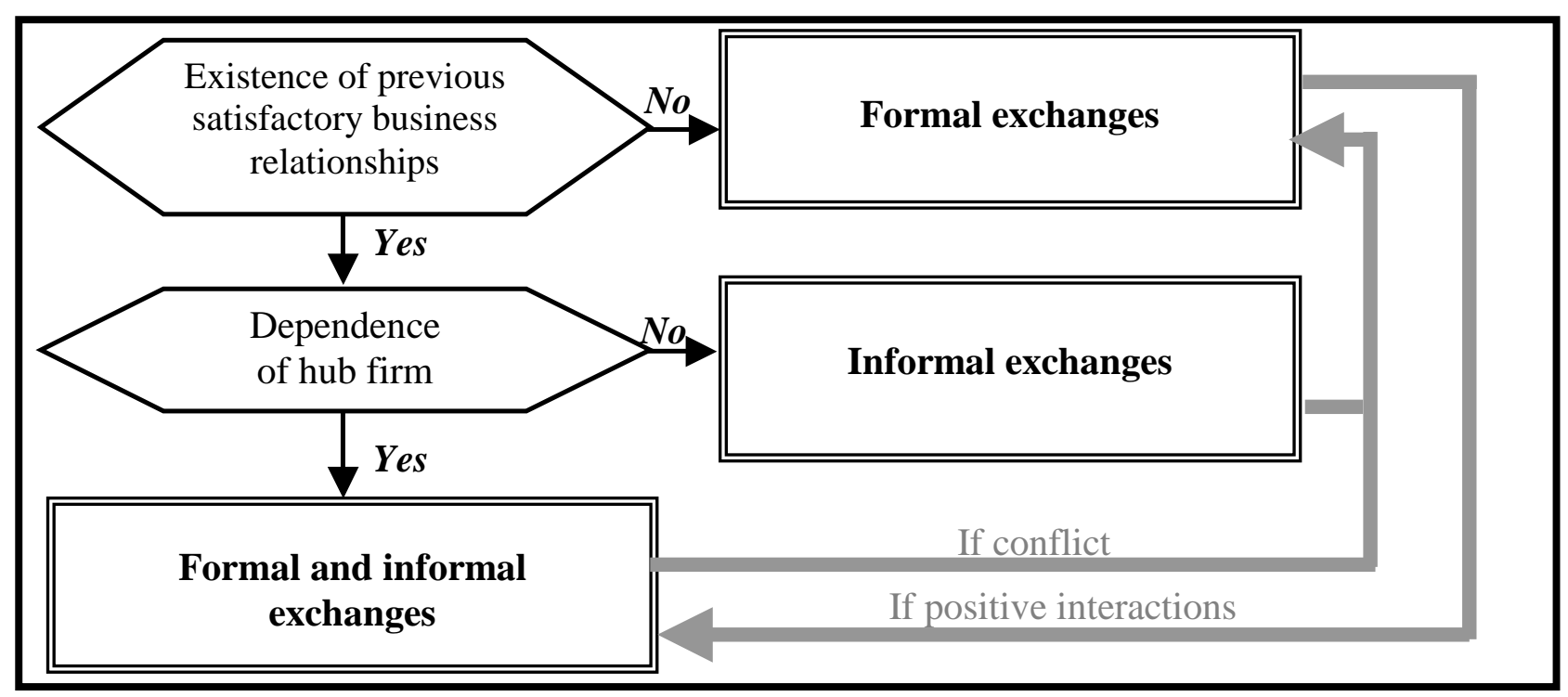


Figure 3 (Re)Defining trust

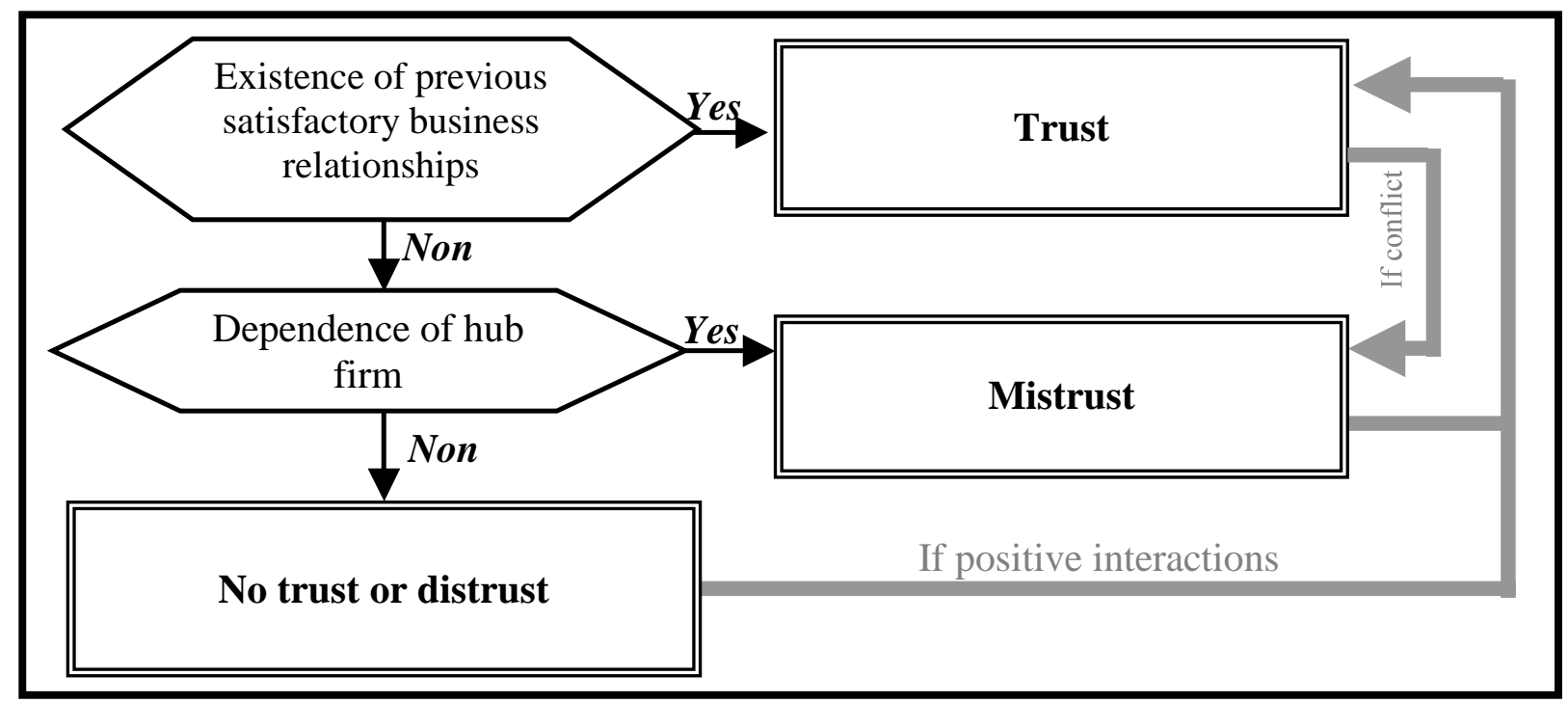

Figure 4 (Re)Defining outcome divisions

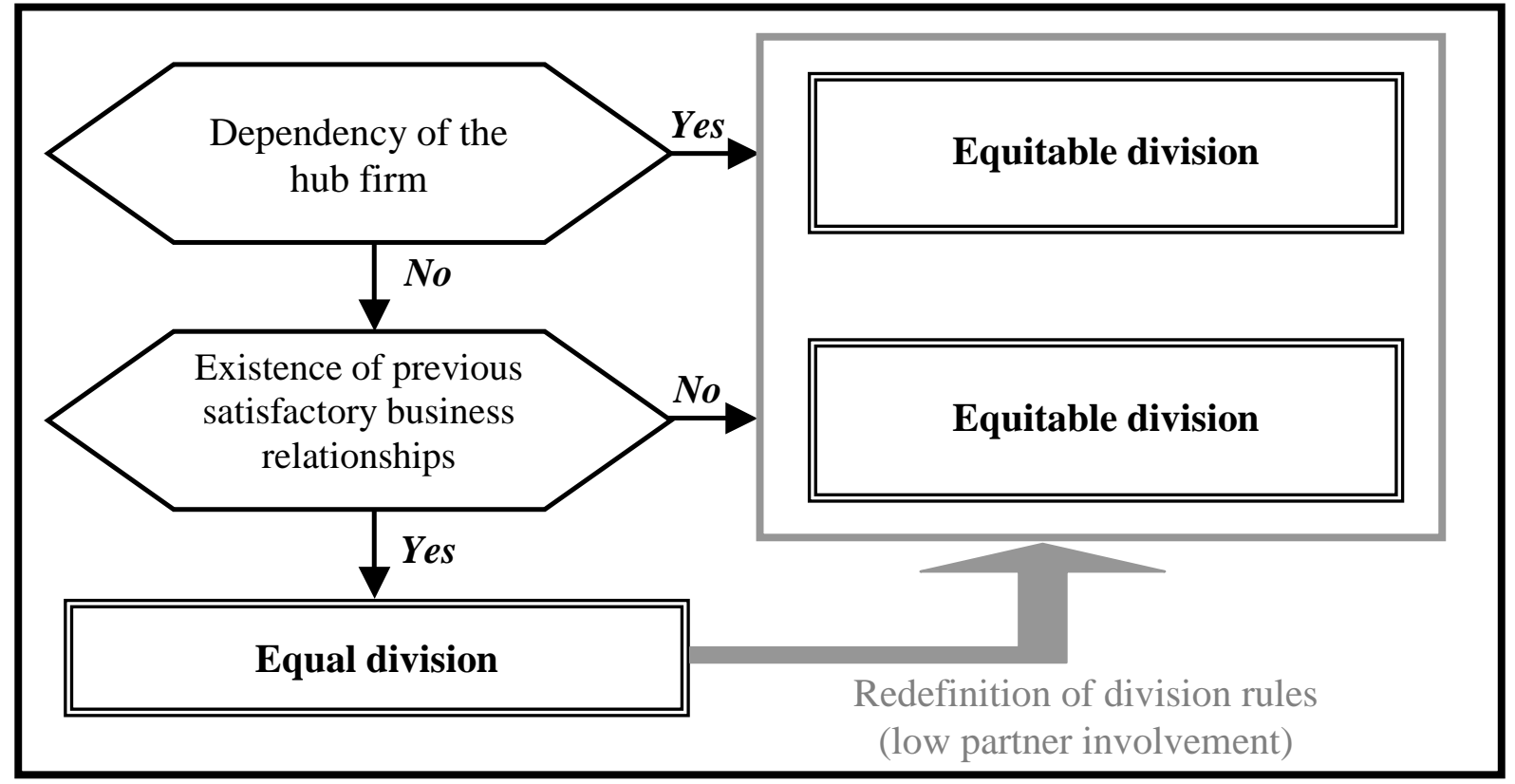


Figure $5 \quad(\operatorname{Re})$ Defining guarantees

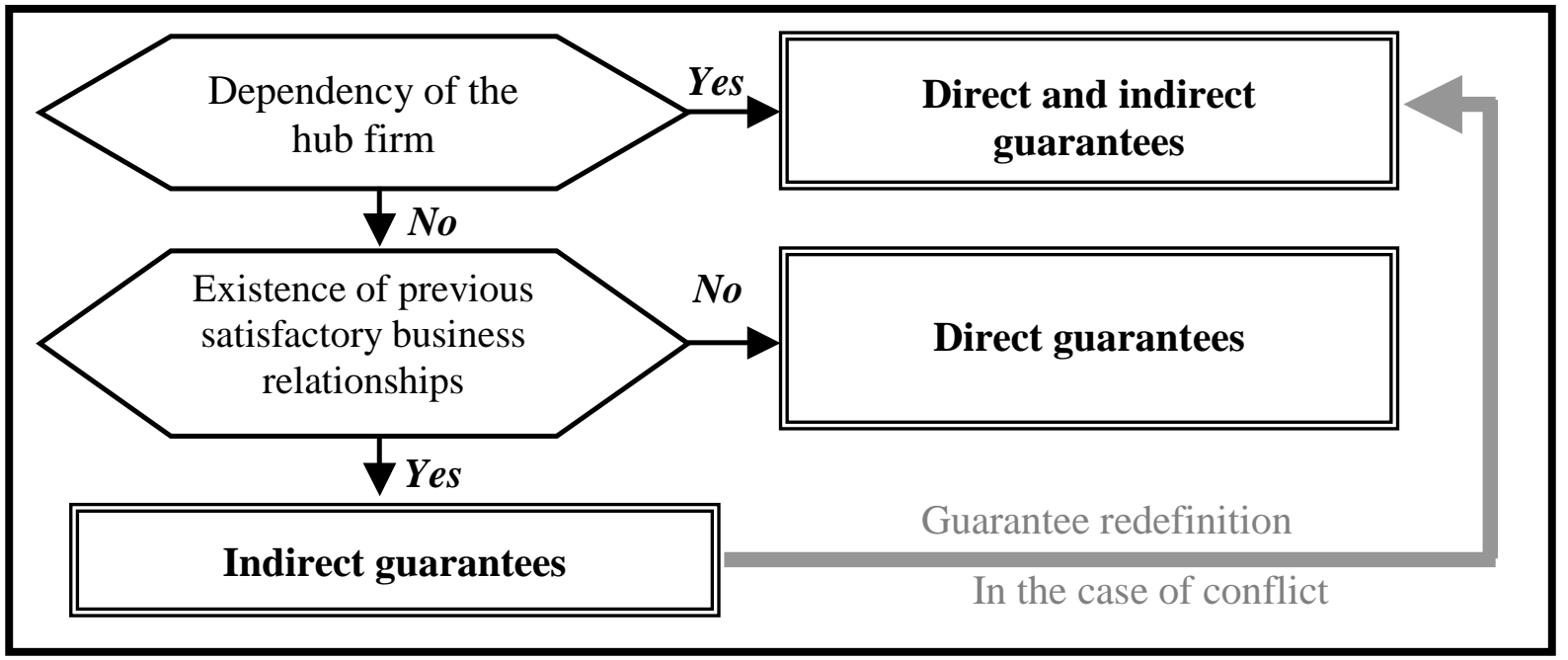

Figure 6 (Re)Defining conflict resolution forms

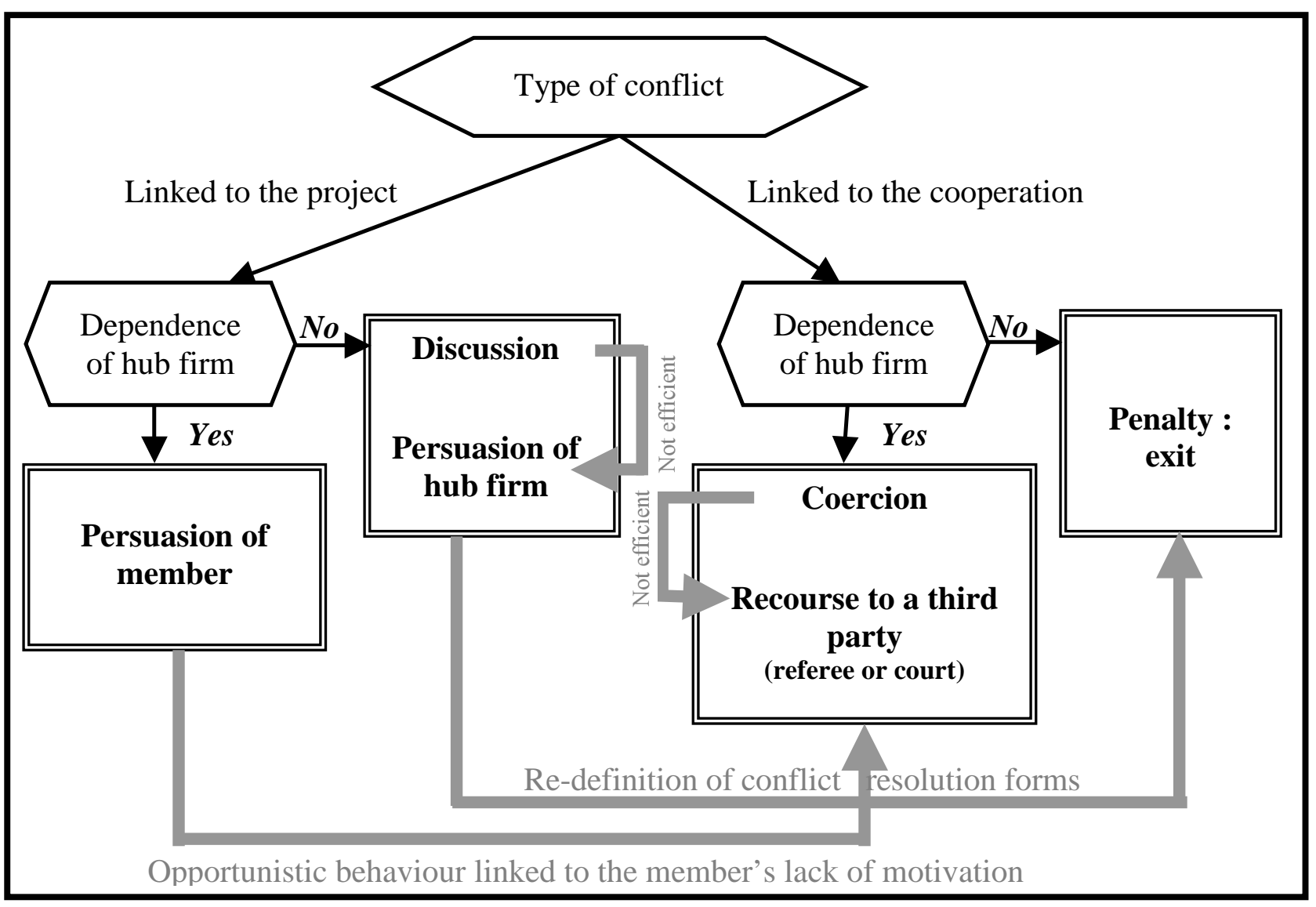


Table 1 Six innovation networks

\begin{tabular}{|c|c|l|c|c|c|}
\hline Project & Hub firm & $\mathbf{M}^{*}$ & Subject & $\begin{array}{c}\text { Business } \\
\text { sector }\end{array}$ & Characteristics \\
\hline $\begin{array}{c}\text { Project A } \\
\text { Motorisation }\end{array}$ & $\begin{array}{c}\text { SME } \\
\text { (12 people) }\end{array}$ & 65 & $\begin{array}{c}\text { Essential component } \\
\text { for automobile } \\
\text { manufacturers }\end{array}$ & Automotive & $\begin{array}{c}\text { Highly ambitious: very high } \\
\text { investment and highly technical }\end{array}$ \\
\hline $\begin{array}{c}\text { Project B } \\
\text { Pinc\&Pile }\end{array}$ & $\begin{array}{c}\text { SME } \\
\text { (2 people) }\end{array}$ & 8 & $\begin{array}{c}\text { Product for } \\
\text { beauticians } \\
\text { (business-to- } \\
\text { business })\end{array}$ & $\begin{array}{c}\text { Large-scale } \\
\text { retail }\end{array}$ & $\begin{array}{c}\text { Significant conflict; the } \\
\text { commercial and industrial } \\
\text { partners claimed property rights } \\
\text { on patents already filed }\end{array}$ \\
\hline $\begin{array}{c}\text { Project C } \\
\text { Telescopic }\end{array}$ & $\begin{array}{c}\text { Independent } \\
\text { (1 person) }\end{array}$ & 11 & $\begin{array}{c}\text { Product for } \\
\text { everyday use }\end{array}$ & $\begin{array}{c}\text { Large-scale } \\
\text { retail }\end{array}$ & $\begin{array}{c}\text { Stagnant project; oligopolist } \\
\text { target market leading to } \\
\text { distribution problems }\end{array}$ \\
\hline $\begin{array}{c}\text { Project D } \\
\text { Transparts }\end{array}$ & $\begin{array}{c}\text { SME } \\
\text { (3 people })\end{array}$ & 9 & $\begin{array}{c}\text { Machine improving } \\
\text { the processing of } \\
\text { small parts }\end{array}$ & $\begin{array}{c}\text { Industry } \\
\text { Opportunistic behaviour by } \\
\text { commercial partner, with } \\
\text { complementary patent filed } \\
\text { without notification }\end{array}$ \\
\hline $\begin{array}{c}\text { Project E } \\
\text { Protect }\end{array}$ & $\begin{array}{c}\text { SME } \\
\text { (6 people })\end{array}$ & 24 & Protection for sports & $\begin{array}{c}\text { Sports and } \\
\text { leisure }\end{array}$ & $\begin{array}{c}\text { Project running successfully } \\
\text { without too many problems }\end{array}$ \\
\hline $\begin{array}{c}\text { Project F } \\
\text { Jump }\end{array}$ & $\begin{array}{c}\text { Independent } \\
\text { (1 person) }\end{array}$ & 6 & Sports material & $\begin{array}{c}\text { Sports and } \\
\text { leisure }\end{array}$ & $\begin{array}{c}\text { Hub firm benefited from the } \\
\text { experience of another project } \\
\text { sponsor }\end{array}$ \\
\hline
\end{tabular}

* Number of members 
Table 2 Data collected

\begin{tabular}{|c|c|c|c|c|}
\hline $\begin{array}{l}\text { Information } \\
\text { sources }\end{array}$ & Interviews & $\begin{array}{c}\text { Frequency and } \\
\text { total duration } \\
\text { of passive } \\
\text { observations } \\
\end{array}$ & Internal data & External data \\
\hline Motorisation (A) & $\begin{array}{c}13 \\
5 \text { hub firms } \\
5 \text { technical members } \\
2 \text { financial members } \\
1 \text { industrial member }\end{array}$ & $\begin{array}{l}\text { Very frequent } \\
7 \text { days }\end{array}$ & $\begin{array}{c}\text { Contracts (7) } \\
\text { Funding request files } \\
\text { (2) }\end{array}$ & $\begin{array}{c}\text { Internet site } \\
54 \text { press articles }\end{array}$ \\
\hline Pinc\&pile (B) & $\begin{array}{c}\mathbf{9} \\
3 \text { hub firms } \\
2 \text { legal members } \\
1 \text { technical member } \\
1 \text { financial member } \\
2 \text { industrial members }\end{array}$ & $\begin{array}{l}\text { Frequent } \\
3 \text { days }\end{array}$ & $\begin{array}{l}\text { Contracts (3) } \\
\text { File for innovating } \\
\text { project contests (1) }\end{array}$ & 20 press articles \\
\hline Telescopic(C) & $\begin{array}{c}\mathbf{6} \\
2 \text { hub firms } \\
1 \text { legal member } \\
2 \text { technical members } \\
1 \text { financial member }\end{array}$ & $\begin{array}{l}\text { Not frequent } \\
1 \text { day }\end{array}$ & $\begin{array}{c}\text { Meeting reports }(8) \\
\text { Email exchanges }(50)\end{array}$ & $\begin{array}{c}\text { Internet site } \\
28 \text { press articles }\end{array}$ \\
\hline Transparts (D) & $\begin{array}{c}7 \\
2 \text { hub firms } \\
2 \text { legal members } \\
2 \text { financial members } \\
1 \text { commercial member }\end{array}$ & $\begin{array}{l}\text { Not frequent } \\
1 \text { day }\end{array}$ & $\begin{array}{l}\text { Email exchanges (25) } \\
\text { Legal mails from } \\
\text { lawyers (13) }\end{array}$ & $\begin{array}{c}\text { Internet site } \\
12 \text { press articles }\end{array}$ \\
\hline Protect $(\mathbf{E})$ & $\begin{array}{c}\mathbf{1 0} \\
4 \text { hub firms } \\
1 \text { legal member } \\
3 \text { technical members } \\
1 \text { industrial member } \\
1 \text { commercial member }\end{array}$ & $\begin{array}{l}\text { Very frequent } \\
5 \text { days }\end{array}$ & $\begin{array}{c}\text { Contracts (16) } \\
\text { Email exchanges (10) }\end{array}$ & $\begin{array}{c}\text { Internet site } \\
35 \text { press articles }\end{array}$ \\
\hline Jump (F) & $\begin{array}{c}\mathbf{8} \\
2 \text { hub firms } \\
1 \text { financial member } \\
2 \text { technical members } \\
1 \text { industrial member } \\
2 \text { commercial members } \\
\end{array}$ & $\begin{array}{l}\text { Not frequent } \\
2 \text { day }\end{array}$ & $\begin{array}{c}\text { Contracts (3) } \\
\text { Email exchanges (20) }\end{array}$ & $\begin{array}{c}\text { Internet site } \\
8 \text { press articles }\end{array}$ \\
\hline
\end{tabular}




\section{Appendix 1 Coordination mechanisms and forms in an innovation network}

\begin{tabular}{|c|c|c|c|}
\hline $\begin{array}{c}\text { Coordination } \\
\text { mechanism }\end{array}$ & Mode & $\begin{array}{c}\begin{array}{c}\text { Underlying } \\
\text { theory }\end{array} \\
\end{array}$ & Definition \\
\hline \multirow{2}{*}{$\begin{array}{c}\text { Exchange } \\
\text { formalisation } \\
\text { (Lee and } \\
\text { Cavusgil, 2006) }\end{array}$} & Formal & \multirow{2}{*}{$\begin{array}{l}\text { Contractual } \\
\text { and trust } \\
\text { approach }\end{array}$} & $\begin{array}{l}\text { The use of a formalised, legally binding agreement or a } \\
\text { contract to govern the inter-firm partnership. }\end{array}$ \\
\hline & Informal & & $\begin{array}{l}\text { The role of discussion, commitment, and relational capital } \\
\text { in the governance process. }\end{array}$ \\
\hline \multirow[t]{2}{*}{$\begin{array}{c}\text { Trust } \\
\text { (Mesquita, } \\
\text { 2007) }\end{array}$} & Trust & \multirow[t]{2}{*}{$\begin{array}{c}\text { Relational and } \\
\text { contractual }\end{array}$} & $\begin{array}{l}\text { The confident positive willingness of one to be vulnerable } \\
\text { to the conduct of another in conditions of interdependence } \\
\text { and risk. "Confident positive" means that one will } \\
\text { purposefully act on the basis of another's conduct, } \\
\text { "interdependence" means that one cannot realise the } \\
\text { expected economic outcomes without cooperation with the } \\
\text { other, "risk" refers to the probability of loss as perceived } \\
\text { by the decision maker. The decision to be vulnerable } \\
\text { occurs when the trustor believes in the trustee's abilities, } \\
\text { benevolence, and integrity. }\end{array}$ \\
\hline & Distrust & & $\begin{array}{l}\text { Confident negative willingness to be vulnerable to the } \\
\text { conduct of another under conditions of risk and } \\
\text { interdependence. }\end{array}$ \\
\hline \multirow[b]{2}{*}{$\begin{array}{l}\text { Result division } \\
\quad(\mathrm{Jap}, 2001)\end{array}$} & Equal & & $\begin{array}{l}\text { Each party receives an equal share of the payoffs-a } 50 / 50 \\
\text { split. }\end{array}$ \\
\hline & Equitable & $\begin{array}{l}\text { Agency and } \\
\text { incomplete } \\
\text { contractual }\end{array}$ & $\begin{array}{l}\text { Each member's payoffs are a function of resources } \\
\text { provided (tangible and intangible contributions, costs } \\
\text { incurred) to the collaboration. Derived from equity theory, } \\
\text { which states that people judge an outcome as fair when the } \\
\text { ratio of their own resources and output equals the ratio of } \\
\text { resources and output of others. }\end{array}$ \\
\hline \multirow[b]{2}{*}{$\begin{array}{l}\text { Guarantees } \\
\text { against } \\
\text { opportunistic } \\
\text { behaviour } \\
\text { (Brousseau, } \\
\text { 2000) }\end{array}$} & Direct & Contractual & Immediate effect to control the behaviour of members. \\
\hline & Indirect & Contractual & $\begin{array}{l}\text { Impact at later time, based on the ability to harm the } \\
\text { reputation of a member or limit future business } \\
\text { opportunities. }\end{array}$ \\
\hline \multirow{5}{*}{$\begin{array}{c}\text { Conflict } \\
\text { resolution } \\
\text { (Mohr and } \\
\text { Spekman, 1994) }\end{array}$} & Discussion & Relational & $\begin{array}{l}\text { Joint problem solving. Different groups come together to } \\
\text { find a mutual solution for a problem. }\end{array}$ \\
\hline & Persuasion & Relational & $\begin{array}{l}\text { Partners attempt to persuade each other to adopt particular } \\
\text { solutions. }\end{array}$ \\
\hline & Coercion & $\begin{array}{c}\text { Relational and } \\
\text { contractual }\end{array}$ & $\begin{array}{l}\text { One or many partner(s) restrain others from choosing the } \\
\text { conflict resolution solution. }\end{array}$ \\
\hline & Sanction & Contractual & Excluding the partner from the innovation network. \\
\hline & $\begin{array}{l}\text { Third-party } \\
\text { arbitration }\end{array}$ & Contractual & A third party (arbitrator or court) provides the solution. \\
\hline
\end{tabular}


Appendix 2 Dependence, prior relations and conflict type

\begin{tabular}{|c|c|c|}
\hline Sources & Dimension & Coordination mechanisms \\
\hline $\begin{array}{c}\text { Gencturk and Aulakh, } 1995 \\
\text { Baliga and Jaeger, } 1984 \\
\text { Ambos and Schlegelmilch, } 2007 \\
\text { Gupta and Govindarajan, } 1991\end{array}$ & Dependence & Formalisation/control level \\
\hline Kumar et al., 1995 & Dependence & Trust and confidence \\
\hline $\begin{array}{c}\text { Doz, } 1988 \\
\text { Siriam et al., } 1992\end{array}$ & Dependence & Sharing of benefits \\
\hline Lui et al., 2006 & Dependence & Guarantee systems \\
\hline $\begin{array}{l}\text { Kumar et al., } 1998 \\
\text { Lui et al., } 2006\end{array}$ & Dependence & Conflict resolution mechanisms \\
\hline $\begin{array}{l}\text { Ring and Van de Ven, } 1994 \\
\text { Inkpen and Currall, } 2004\end{array}$ & Prior relations & Trust \\
\hline $\begin{array}{c}\text { Doz, } 1996 \\
\text { Lui et al., } 2006\end{array}$ & Prior relations & Formalisation \\
\hline Gulati, 1995b & Prior relations & Trust/contractual safeguards \\
\hline Klein, 1980 & Prior relations & Safeguards \\
\hline Reuer and Arino, 2007 & Prior relations & Conflict resolution mechanisms \\
\hline Amason, 1996 & Conflict type & $\begin{array}{c}\text { Conflict } \\
\text { resolution/formalisation }\end{array}$ \\
\hline Lee and Cavusgil, 2006 & Conflict type & Formalisation \\
\hline $\begin{array}{l}\text { Morgan and Hunt, } 1994 \\
\text { Lusch and Brown, } 1996\end{array}$ & Conflict type & Trust \\
\hline
\end{tabular}




\section{Appendix 3 The six case studies}

Motorisation. The project emerged as a result of two situational factors: the evolution of regulation and the difficult introduction of hybrid vehicles. Greater political awareness prompted new regulations for energy savings and environmental responsibility for vehicles. The difficulty of mass producing hybrid vehicles created high production costs relative to performance; opportunities to reduce these costs remained limited by the use of old technologies (electric motors, batteries). The hub firm selected partners and sub-contractors on the basis of their technological capabilities. The technical complexity of the project required a lot of $\mathrm{R} \& \mathrm{D}$, and the total cost (estimated at 5500K€) required many financial and technical partners.

Pinc\&pile. Regardless of disinfection efforts, the hygiene of conventional tweezers is sub-optimal, so Pinc\&pile attempted to address a previously unsolvable problem, from both technical (creation of the mould) and financial (high production costs, $2 €$ per clip) perspectives. The project involves the creation of disposable tweezers in recyclable plastic. To build the network, the hub firm paid a particular attention to (1) prior relationships and chose cooperation with members with which it had already worked, even if they lacked a strong reputation; (2) degree of motivation and involvement and (3) skills.

Telescopic. Recognising the lack of hygiene in warehouses in emerging countries, the hub firm thought about a more healthy system and filed patents to improve the uses of certain types of packaging. Its innovation consists of releasing a straw from the can at the end of the manufacturing process to improve the cleanliness of canned beverages. The hub firm chose members according to their area of expertise. Telescopic comprised many members, including financial supporters; the investment is estimated at more than $800 \mathrm{~K} €$.

Transparts. The hub firm, after two decades of experience in the development of special machines (conveyor systems for basic parts to be assembled), moved to realise standard industrial solutions to solve or simplify problems related to components on assembly machines. It devised a system of rotating cams, driven by a motor, which represented a technical feat. With its great versatility, the invention has given the hub firm success in various markets such as automobiles, explosives (with a flameproof motor) and cosmetics.

Protect. The hub firm specialised in helping create consumer products, mainly for suppliers of sports equipment. The design of the headphone product at the centre of this project included a deformable structure that easily adapted to the user's morphology. The hub firm surrounded itself with partners and sub-contractors that provided access to a broad range of resources and skills. Each member assumed a specific role according to the allocation of tasks. The potential innovation could be partially modular, such that its independent parts could be developed separately and in parallel, according to standard design rules and interfaces. The hub firm and partners focused on core activities, such as design and manufacture, and thus retained non-substitutable strategic resources; sub-contractors took charge of the lower value-added components.

Jump. A ski and snowboarding coach was frustrated by the lack of progress by students in the summer season, so he developed a small-scale board to enable training on trampolines. Skiers adopted it quickly; they learned to orient themselves in space through repeated jumps and to safely perform compulsory figures. The encouraging results of this test phase led the innovator to start a company to develop and commercialise Jump as not only a teaching tool for advanced training but also a fun object to help master jumps in the air. Member selection mainly proceeded through word of mouth and Internet connections. Both ways provided quick solutions, added skills or supported the purchase of equipment through central purchasing routes. 